\title{
The Relation of Musculoskeletal Discomfort with Body Mass Index (BMI) For Cleaning Workers, Who Work at an Elevated Place
}

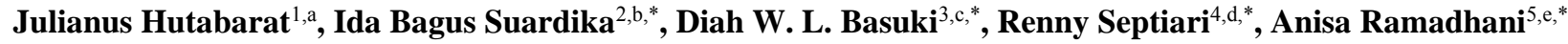 \\ 1, 2, 3,4 Industrial Engineering, Institute of National Technology Malang, Indonesia. \\ ${ }^{5}$ Magister Program, Postgraduate Institute of National Technology, Malang, Indonesia. \\ ORCID: https://orcid.org/0000-0002-1581-6198 (Corresponding author),
}

\begin{abstract}
The purpose of this research was to determine the extent of the influence of Body Mass Index (BMI) Variations on musculoskeletal discomfort. The steps taken are first to calculate the Body Mass Index (BMI), measure the level of musculoskeletal discomfort of each cleaning worker who works in an elevated place by distributing the Nordic Body Map questionnaire, then perform a statistical test with the ChiSquare Test. The results of this research are painful areas of musculoskeletal discomfort is the left shoulder, right shoulder, back, waist, buttocks, right knee and left leg. From the ChiSquare Test results obtained $\mathrm{p}$-value for the left shoulder $=$ 0.006 , right shoulder $=0.003$, back $=0.00$, waist $=0.00$, buttocks $=0.00$, right $\mathrm{knee}=0.001$ and left leg $=0.00$, because all $<0.05$ then all null hypotheses are rejected, this fact means there is a relationship between BMI and musculoskeletal discomfort that is felt sick. The conclusion is an un-ergonomic posture in the work will cause the musculoskeletal discomfort area and the higher the person's BMI level will be susceptible to pain complaints, the lower the BMI than the fewer complaints of pain.
\end{abstract}

Keywords: Body Mass Index (BMI), Musculoskeletal Discomfort, Cleaning Workers, Work in an elevated place.

\section{INTRODUCTION}

Cleaning workers are cleaners who need physical strength. They need to work not only on the ground floor, but also on the upper floor, or work at heights inside and outside the building. The purpose of this study was to allow participants to work outside the building, clean the high-altitude glass, and use the stairs as a base to work. From the observation results if observed posture when cleaning workers work, body position tilted and bent with angles ranging from $20^{\circ}-60^{\circ}$, neck bent with an angle of about $20^{\circ}$, cleaning done repeatedly by sliding the left hand and right hand with the upper arm angle $>$ $90^{\circ}$ raised for 10 minutes and forearm around $40^{\circ}$, this illustrates the condition of Awkward posture cleaning workers are not ergonomic, the posture that is not ergonomic will cause musculoskeletal disorder (MacLeod, 1995).

Nordic Body Map is a mapping of painful area of musculoskeletal discomfort when working, there are 27 points that are the focus of observation in areas of the human body
(Kilroy, N. and Sara, D., 2000), work postures that are not ergonomic will cause the occurrence of musculoskeletal discomfort in areas certain in the body that feels pain (Hayati et al., 2014).

Participants' Body Mass Index (BMI) also varied, Body Mass Index (BMI) averaged $23.14 \mathrm{~kg} / \mathrm{m}^{2} \pm 3.88$ from the initial survey results related to the relationship with musculoskeletal discomfort describing the different variations of complaints in each participant and according to (Maulana et al. 2016) BMI has a strong relationship with pain in Low Back Pain (LBP), according to (Kridianto et al. 2015) Body Mass Index (BMI) has a significant relationship with musculoskeletal complaints due to work. In this study, we will look for answers to musculoskeletal discomfort to the question of which areas have complained when working at height, and the extent of the relationship of BMI to complaints of musculoskeletal discomfort.

\section{METHOD}

Cleaning workers used as participants in this tudy are those who work at the National Technology Institute of Malang-East Java- Indonesia, selected participants are all men who do not have a history of high blood pressure, heart disease and diabetes as many as 30 people. Participant demographics: Mean age 35 years \pm 7.61 ; Average body weight $64 \mathrm{~kg} \pm$ 11.17; Average height $163 \mathrm{~cm} \pm 4.00$; Body Mass Index (BMI) averaging $23.14 \mathrm{~kg} / \mathrm{m}^{2} \pm 3.88$. They work from 7 am to $4 \mathrm{pm}$ with a break from 12.00 to 13.00 .

Materials used to clean the glass include: glass cleaner (spiritus), used paper to clean the glass surface and cloth rags to clean the glass surface.

The tools used include bed sheet as a place, a ladder as a tool to go up to the area to be cleansed and as a place to foot when working, kapi is a tool to wipe spiritus water that sprayed on the glass surface of rubber material.

This sudy was first conducted by distributing the Nordic Body Chart questionnaire, which contains 27 questions, of which there are 4 (four) types of complaints selected: No pain, slight pain, illness and very ill to 30 participants who worked cleaning the glass outside the building at a height, then processed by using excel and obtained any musculoskeletal discomfort area which felt to be sickly, for further calculations, the grouping of 
International Journal of Engineering Research and Technology. ISSN 0974-3154, Volume 13, Number 5 (2020), pp. $938-942$

(C) International Research Publication House. https://dx.doi.org/10.37624/IJERT/13.5.2020.938-942

complaints will be grouped into 2 (two) groups: Pain and no pain where pain includes rather sickly, sickly and very sick. Furthermore, statistical tests performed with the Chi- Square Test, to determine the relationship of BMI with each area of discomfort felt musculoskeletal pain. In this case, the BMI category: $<17 \mathrm{Kg} / \mathrm{m}^{2}$ thinner (underweight) $17-18.5 \mathrm{Kg} / \mathrm{m}^{2}$ is thin (underweight lightweight), $18.25-25 \mathrm{Kg} / \mathrm{m}^{2}$ is normal, $25-27$ is fat (overweight at a mild level) and $>27 \mathrm{~kg} / \mathrm{m}^{2}$ is fat (overweight at a heavy level). In the next calculation, it will be simplified into 2 (two) categories, namely fat and not fat, where fat includes overweight and lightweight overweight, then not to fat includes normal and thin.

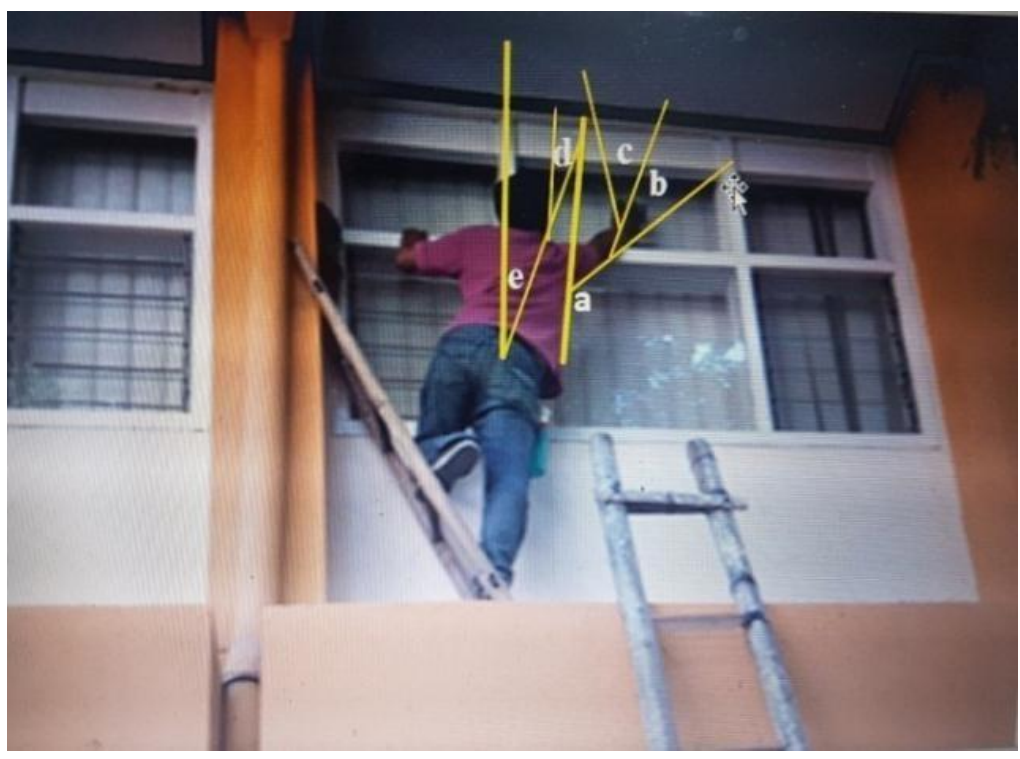

Fig. 1 Body Posture When Cleansing Glass at an Elevated Place

Body postures when working in an elevated place as shown in figure 1. Position the angle of the upper $\operatorname{arm}(\mathrm{a})=130^{\circ}$;
Forearm angle $(\mathrm{b})=40^{\circ}$, wrist angle $=35^{\circ}$, neck angle $=20^{\circ}$, trunk angle $=30^{\circ}$ and position of one leg raised.

\section{RESULTS}

Table 1. BMI and Participant Categories.

\begin{tabular}{cccccc}
\hline Participant & BMI & Category & Participant & BMI & Category \\
\hline 1 & 21,48 & Not Fat & 16 & 32.89 & Fat \\
2 & 24,97 & Not Fat & 17 & 26,72 & Fat \\
3 & 25,91 & Fat & 18 & 26.72 & Fat \\
4 & 25,71 & Fat & 19 & 26.95 & Fat \\
5 & 13,67 & Not Fat & 20 & 25.25 & Fat \\
6 & 26,56 & Fat & 21 & 21,48 & Not Fat \\
7 & 23,87 & Not Fat & 22 & 24,97 & Not Fat \\
8 & 23,87 & Not Fat & 23 & 25,91 & Fat \\
9 & 26,72 & Fat & 24 & 25,71 & Fat \\
10 & 18,59 & Not Fat & 25 & 13,67 & Not Fat \\
11 & 25,71 & Fat & 26 & 26,56 & Fat \\
12 & 22.32 & Not Fat & 27 & 23,87 & Not Fat \\
13 & 20.76 & Not Fat & 28 & 23,87 & Not Fat \\
14 & 26.22 & Fat & 29 & 26,72 & Fat \\
15 & 24.50 & Not Fat & 30 & 18,59 & Not Fat \\
\hline
\end{tabular}


International Journal of Engineering Research and Technology. ISSN 0974-3154, Volume 13, Number 5 (2020), pp. $938-942$

(C) International Research Publication House. https://dx.doi.org/10.37624/IJERT/13.5.2020.938-942

BMI category grouping as in table 1. is a simplification of 5 (five) BMI groups, into 2 groups, namely the group with fat and not fat categories, where non-fat includes normal and thin categories (underweight and lightweight) with $\mathrm{BMI}<25$, for fat including light and heavy fat wherewith a BMI $\geq 25$, found $50 \%$ of the participants included in the thin category and $50 \%$ in the fat category.

Table 2. Areas of Musculoskeletal Discomfort that are felt sick $>50 \%$.

\begin{tabular}{ccc}
\hline No & Musculoskeletal Pain & Percentage \\
\hline 1 & Left Shoulder & $80 \%$ \\
2 & Right Shoulder & $76 \%$ \\
3 & Backs & $70 \%$ \\
4 & Waist & $63 \%$ \\
5 & Buttocks & $67 \%$ \\
6 & Right Knee & $74 \%$ \\
7 & Left Foot & $70 \%$ \\
\hline
\end{tabular}

From the results of a questionnaire of 30 participants and from 27 musculoskeletal areas, more than $50 \%$ of the area felt was pain in 7 (seven) areas, namely the left shoulder, right shoulder, back, waist, buttocks, right knee and left leg as in Table 2 .

Table 3. Summary of Cross tabulation Relationship between BMI and Pain Complaints

\begin{tabular}{|c|c|c|c|c|}
\hline \multicolumn{5}{|c|}{ Crosstab } \\
\hline & & \multicolumn{2}{|c|}{$B M I$} & \multirow{2}{*}{ Total } \\
\hline & & Not Fat & Fat & \\
\hline \multirow{2}{*}{ Left Shoulder } & Painless & 6 & 0 & 6 \\
\hline & Pain & 9 & 15 & 24 \\
\hline Total & & 15 & 15 & 30 \\
\hline \multirow[t]{2}{*}{ Right Shoulder } & Painless & 7 & 0 & 7 \\
\hline & Pain & 8 & 15 & 23 \\
\hline Total & & 15 & 15 & 30 \\
\hline \multirow[t]{2}{*}{ Backs } & Painless & 9 & 0 & 9 \\
\hline & Pain & 6 & 15 & 21 \\
\hline Total & & 15 & 15 & 30 \\
\hline \multirow[t]{2}{*}{ Waist } & Painless & 11 & 0 & 11 \\
\hline & Pain & 4 & 15 & 19 \\
\hline Total & & 15 & 15 & 30 \\
\hline \multirow[t]{2}{*}{ Buttocks } & Painless & 10 & 0 & 10 \\
\hline & Pain & 5 & 15 & 20 \\
\hline Total & & 15 & 15 & 30 \\
\hline \multirow[t]{2}{*}{ Right Knee } & Painless & 8 & 0 & 8 \\
\hline & Pain & 7 & 15 & 22 \\
\hline Total & & 15 & 15 & 30 \\
\hline \multirow[t]{2}{*}{ Left Foot } & Painless & 9 & 0 & 9 \\
\hline & Pain & 6 & 15 & 21 \\
\hline Total & & 15 & 15 & 30 \\
\hline
\end{tabular}


International Journal of Engineering Research and Technology. ISSN 0974-3154, Volume 13, Number 5 (2020), pp. $938-942$

(C) International Research Publication House. https://dx.doi.org/10.37624/IJERT/13.5.2020.938-942

Relationship of the spread of pain and no pain in 7 (seven) areas of musculoskeletal discomfort and BMI as shown in table 3. It appears that participants with obese categories all felt pain in 7 (seven) areas of musculoskeletal discomfort and participants with the category of non-obese BMI 57\% felt no sick and $43 \%$ feel pain.

Table 4. Results of Chi-Square Left Shoulder Tests

\begin{tabular}{|c|c|c|c|c|c|}
\hline \multicolumn{6}{|c|}{ Chi-Square Tests } \\
\hline & Value & $\mathrm{DF}$ & $\begin{array}{l}\text { Asymptotic Significance } \\
\text { (2-sided })\end{array}$ & $\begin{array}{l}\text { Exact Sig. } \\
\text { (2-sided) }\end{array}$ & $\begin{array}{l}\text { Exact Sig. } \\
\text { (1-sided) }\end{array}$ \\
\hline Pearson Chi-Square & $7,500^{\mathrm{a}}$ & 1 & 0,006 & & \\
\hline Continuity Correction ${ }^{b}$ & 5,208 & 1 & 0,022 & & \\
\hline Likelihood Ratio & 9,834 & 1 & 0,002 & & \\
\hline Fisher's Exact Test & & & & 0,017 & 0,008 \\
\hline $\begin{array}{l}\text { Linear-by-Linear } \\
\text { Association }\end{array}$ & 7,25 & 1 & 0,007 & & \\
\hline $\mathrm{N}$ of Valid Cases & 30 & & & & \\
\hline
\end{tabular}

a. 2 cells $(50 \%)$ have expected count less than 5 . The minimum expected count is 3,00 .

b. Computed only for a $2 \times 2$ table

In Table 4. Describing the results of Chi-Square Tests, the relationship of BMI with pain in the left shoulder obtained pvalue significance of 0.006 and chi-square value of 7.5. Because the significance value $0.006<(0.05)$ and chi-square count $7.5>3.841$ (chi-square table), the null hypothesis rejected, which means that there is a real relationship between BMI and Left Shoulder complaints. This means that the higher the level of BMI, the more susceptible to complaints of pain in the left shoulder.

Table 5. Summary of Chi-Square Tests Results for 7 Musculoskeletal Areas

Chi-Square Tests

\begin{tabular}{|c|c|c|c|c|}
\hline $\begin{array}{l}\text { Musculoskeletal } \\
\text { Pain }\end{array}$ & Pearson Chi-Square Value & $\begin{array}{c}\text { Asymptotic Significance } \\
\text { (2-sided) }\end{array}$ & $\begin{array}{l}\text { chi-square } \\
\text { table }\end{array}$ & Null Hypothesis \\
\hline Left Shoulder & 7,500 & 0,006 & 3,841 & Rejected \\
\hline Right Shoulder & 9,130 & 0,003 & 3,841 & Rejected \\
\hline Backs & 12,857 & 0,000 & 3,841 & Rejected \\
\hline Waist & 17,368 & 0,000 & 3,841 & Rejected \\
\hline Buttocks & 15,000 & 0,000 & 3,841 & Rejected \\
\hline Right Knee & 10,909 & 0,001 & 3,841 & Rejected \\
\hline Left Foot & 12,857 & 0,000 & 3,841 & Rejected \\
\hline
\end{tabular}

In Table 5. Describing the summary of all Chi-Square Tests results for 7 (seven) painful areas of musculoskeletal discomfort, the Chi-Square Tests results show that all null hypotheses rejected, this illustrates that there is a strong relationship between BMI and musculoskeletal discomfort.
If observed in Figure 1, the participant's body posture in doing the glass cleaning work is not Ergonomic due to the angle of the upper arm $>90^{\circ}$, hanging hand position as well as left leg bent and resting on a small and narrow surface. This illustrates poor posture (Evadariant and Dwiyanti, 2017) the worse the work posture, the greater the musculoskeletal complaints. Un 
Ergonomic work attitudes can also cause musculoskeletal discomfort (Deepak and Ajeesh, 2012).

BMI has a strong relationship with complaints of musculoskeletal discomfort as shown in table 5. It means that if BMI is getting bigger, then musculoskeletal discomfort complaints are also greater according to Figure 1, if left without any improvement or intervention in the workplace and ergonomic work equipment, it can lead to musculoskeletal discomfort (Silva et al, 2013) and can also affect productivity and quality of work (Hutabarat et al, 2013).

\section{CONCLUSION}

For working attitude is not ergonomic on the work of glass cleaning outside the building and at a height than the musculoskeletal area discomfort located on the left shoulder, right shoulder, back, waist, buttocks, right knee and left leg. Body Mass Index has a strong relationship with the emergence of musculoskeletal discomfort complaints, the greater the BMI then the musculoskeletal discomfort increasingly larger, and if not done repair by giving intervention repair worksite or work equipment ergonomically, it can cause musculoskeletal discomfort.

\section{REFERENCES}

[1]. Deepak Sharan, and Ajeesh P.S. 2012. "Article Tittle: Effect of Ergonomic and Workstyle Risk Factors on Work Related Musculoskeletal Disorders among IT Professionals in India”. Work 4 (4): 2872-2875.

[2]. Evadarianto N. and Dwiyanti E. 2017. "Article Tittle: Postur Kerja dengan Keluhan Musculoskeletal Disorders Pada Pekerja Manual Handling bagian Rolling Mill". The Indonesian Journal of Occupational Safety and Health 6 (1): 97-106.
[3]. Hayati K.F., and Kusuma I.F. 2014. "Article Tittle: Muhammad Hasan M.,'The Effect of Working Position on The Incidence of Low Back Pain in The Kampung Sepatu Workers at District Miji-Prajurit KulonMojokerto". e-Journal of Health Library 2 (3): 112-126.

[4]. Hutabarat J, Soeparman S, Pratikto and Santoso PB. 2013. "Article Tittle: Influence of Singing Dancing During a Rest Break Towards Productivity and Product Quality". World Applied Sciences Journal 25(8):12391250 .

[5]. Kilroy, N. and Sara, D. 2000. "Article Tittle: Ergonomic Intervention: Its Effect on Working Posture and Musculoskeletal Symptoms in Female Biomedical Scientists". British Journal of Biomedical Science 57(3): 199.

[6]. Krisdianto, Dewi A.P.S., Ismi. H.R. 2015. “Article Tittle: Hubungan Faktor Individu dan Faktor Pekerjaan dengan Keluhan Muskuloskeletal". Scientific Articles of 2015 Student Research Results.

[7]. MacLeod, D. (1995). The Ergonomics Edge: Improving Safety, Quality, and Productivity. New York: Van Nostrand Reinhold.

[8]. Maulana R.S., Mutiawati E., and Azmunir. 2016. “Article Tittle: Hubungan Indeks Massa Tubuh (IMT) dengan Tingkat Nyeri Pada Penderita Low Back Pain (LBP) di Poliklinik Saraf RSUD dr. Zainoel Abidin Banda Aceh". Scientific Journal of Biomedical Medical Students 1(4):16.

[9]. Moreira-Silva, I., Santos, R., Abreu, S. and Mota, J. 2013. "Article Tittle: Associations between body mass index and musculoskeletal discomfort and related symptoms in different body regions among workers". Sage Open $3(2): 1-6$. 